DOI: $10.1515 /$ lpts-2017-0005

SOLID STATE PHYSICS

\title{
THE STUDY OF ADSORPTION PROCESS OF PB IONS USING WELL- ALIGNED ARRAYS OF ZnO NANOTUBES AS A SORBENT
}

\author{
M. Krasovska, V. Gerbreders, E. Tamanis, S.Gerbreders, A.Bulanovs \\ G.Libert's Innovative Microscopy Centre, Daugavpils University \\ 1 Parades Str., Daugavpils, LV-5401, LATVIA
}

Well-structured $\mathrm{ZnO}$ nanotubes are obtained by a self-selective etching method with lowering temperatures of growth during the hydrothermal process.

The structural and optical properties of the obtained nanostructures are investigated by various conventional methods.

The goal of the research is to compare the efficiency of $\mathrm{ZnO}$ nanotubes to that of $\mathrm{ZnO}$ nanorods during lead adsorption process from aqueous solution and demonstrate that hollow nanostructures are more effective than solid nanostructures of the same morphology due to their larger effective surface.

Both nanotubes and nanorods are obtained under similar growth conditions: neither growth solution composition, nor concentration is changed. $\mathrm{ZnO}$ morphology is switched only by changing temperature during the growth process.

The measurements are carried out to assess the efficiency of the adsorption per unit weight of $\mathrm{ZnO}$ nanorod and nanotube capacity of static adsorption. $\mathrm{ZnO}$.

Keywords: hydrothermal crystal growth, lead adsorption, nanotube,

\section{INTRODUCTION}

Nowadays, due to increased manufacturing and traffic intensity pollution of the environment by heavy metals, such as lead, cadmium, mercury, cobalt, cuprum, arsenic, has become one of the most topical problems [1]-[6].

Heavy metal ions are toxic and cancerogenic; they are accumulated by living organisms causing long-term intoxication and a lot of chronicle and acute diseases [1], [2].

One of the most dangerous environmental pollutants is lead [7]-[9]. As a result of manufacturing, such as leather and textile treatment and fabrication, metalworking, pharmacy, chemical and battery manufacturing etc., it is released into the atmosphere and subterranean waters as well as into soil with further accumulation by plants. 
Due to high hazardous properties of heavy metals, it is very important to minimise humans' contact probability with sources of lead ions, and one of the solutions to this problem is higher purification of wastewater to prevent lead ions from entering the environment.

Various treatment techniques have been developed for the removal of toxic contaminants from wastewater, such as adsorption, ion exchange, chemical precipitation, membrane-based filtration, reverse osmosis, coagulation-sedimentation and so on; however, the most promising and effective method is adsorption [1], [2].

This method is easily performed, inexpensive and sensitive to both organic and nonorganic pollutants, for example, for removal of several kinds of metal ions, organic dues and so on.

In many studies, special attention is devoted to mesoporous and nanostructured materials as a sorbent due to a significantly larger effective area and a higher number of active bounds compared to bulk material of similar composition [4], [7], [10], [11].

$\mathrm{ZnO}$ nanostructures are a promising candidate for many purposes: they are sensitive to all heavy metal ions to a greater or lesser extent and show excellent adsorption results for most hazardous ones, such as lead, cadmium and mercury [2]-[5], [10], [12]. ZnO nanostructures are presented in multiple morphologies and that is why it is possible to change sorption properties depending on the intended purpose and kind of pollutant without changing initial chemicals and sorbent obtaining method. Another important feature is that $\mathrm{ZnO}$ is chemically inactive; therefore, it does not cause secondary pollution.

As shown in [4], $\mathrm{ZnO}$ nanostructures demonstrate good regeneration and reusability without significant loss of sorption capacity for subsequent cycles after three desorption cycles that lower the overall cost of the adsorption process and are environmentally friendly.

\section{MATERIALS AND METHODS}

\subsection{Seed Layer Growth}

Seed layer was obtained to provide orientation of nanotubes along vertical direction during epitaxial growth process and ensure good connection of nanostructure with smooth surface of the substrate.

Previous research [13] shows that one of the most optimal methods for obtaining the seed layer is growing from zinc acetate ethanol solution. Acetate-delivered seed layer provides good crystallinity and orientation along z-direction, and only acetate seed provides needle-like nanorod with sufficiently large diameter for further transformation into nanotubes during a two-step hydrothermal growth process.

Samples were prepared under the following conditions. Glass plates were cleaned by consistent immersing in alkaline and acidic aqueous solutions, several times rinsed with deionized water and dried at $90^{\circ} \mathrm{C}$ for $30 \mathrm{~min}$. Then glass plates were dipped into ultrasonically shaken flask containing $5 \mathrm{mmol}$ Zinc acetate $\mathrm{Zn}\left(\mathrm{CH}_{3} \mathrm{COOH}\right)_{2} * 2 \mathrm{H}_{2} \mathrm{O}$ ethanol solution, then rinsed in pure ethanol and dried with 
nitrogen gas flow.

This procedure was repeated 2-4 times depending on the desired fineness of seed layer. After dipping procedure the samples were annealed at $250^{\circ} \mathrm{C}$ for $30 \mathrm{~min}$ to convert acetate layer to $\mathrm{ZnO}$ during calcination.

\subsection{ZnO Nanotube Growth}

$\mathrm{ZnO}$ nanotubes were obtained using the hydrothermal growth method.

For this purpose $0.1 \mathrm{M}$ equimolar zinc nitrate hexahydrate $\left(\mathrm{Zn}\left(\mathrm{NO}_{3}\right)_{2} * 6 \mathrm{H}_{2} \mathrm{O}\right)$ and hexametientetramine HMTA $\left(\mathrm{C}_{6} \mathrm{H}_{12} \mathrm{~N}_{4}\right)$ aqueous solution were prepared and several chemical reactions took place:

$$
\begin{aligned}
& \mathrm{C}_{6} \mathrm{H}_{12} \mathrm{~N}_{4}+6 \mathrm{H}_{2} \mathrm{O} \rightarrow 6 \mathrm{HCHO}+4 \mathrm{NH}_{3} \\
& \mathrm{NH}_{3}+\mathrm{H}_{2} \mathrm{O} \rightarrow \mathrm{NH}_{4}^{+}+\mathrm{OH}^{-} \\
& 2 \mathrm{OH}^{-}+\mathrm{Zn}^{2+} \leftrightarrow \mathrm{Zn}(\mathrm{OH})_{2} \\
& \mathrm{Zn}(\mathrm{OH})_{2} \leftrightarrow \mathrm{ZnO}+\mathrm{H}_{2} \mathrm{O}
\end{aligned}
$$

In these reactions, zinc nitrate provided the source of $\mathrm{Zn}^{2+}$ ions, but HMTA produced slightly alkaline medium and provided $\mathrm{Zn}^{2+}$ ions with $\mathrm{OH}^{-}$.

All mentioned reactions were in equilibrium and might be shifted from equilibrium condition by changing physical parameters of reaction such as growth temperature, concentration of precursor, $\mathrm{pH}$ and growing time.

In this way, it is possible to obtain nanostructures with tunable morphology, size and density of distribution depending on the initial purposes of research [13].

Working solution was poured into a beaker with lid and then glass plates with seed layer were immersed face downward with the aim to prevent undesirable sedimentation during the chemical reaction.

Beaker was placed into the preheated LINN HIGH THERM furnace and then temperature was maintained $90{ }^{\circ} \mathrm{C}$.

The growing process occurred during two stages:

a. Temperature was set to $90{ }^{\circ} \mathrm{C}$ and maintained for $3 \mathrm{~h}$;

b. Temperature was lowered to $50{ }^{\circ} \mathrm{C}-60{ }^{\circ} \mathrm{C}$ and maintained for $18 \mathrm{~h}-20 \mathrm{~h}$;

This sequence of the process corresponds to the principles of self-selective etching method, when at the first stage in relatively short time at a high temperature the growing process of $\mathrm{ZnO}$ nanorods intensively occurs in both lateral and axial directions, but after lowering the temperature in a significantly longer time period, compared to the first stage, the aging process occurs when $\mathrm{ZnO}$ metastable planes are etched during the chemical reaction with residual chemicals of growth solution [14]-[17].

It should be noted that the growth and aging processes occur at both stages, but at the second stage in constant volume of solution after a long period of growth supply of $\mathrm{Zn}^{2+}$ ions is already exhausted; therefore, growth process of nanotubes is suppressed and the etching processes begin to dominate. 
In comparison with obtaining the nanotubes during chemical etching, the selfselective method has a lot of advantages: it is mild, selective and non-degradable for the whole surface of nanorod (during the indicated time period only metastable planes are etched) and there is no contact with additional chemicals that raises purity of the obtained sample.

As shown in Fig. 1, there are two kinds of nanotubes: the fully etched nanotubes with a deep hole and the ones that are partially formed with low walls and easily visible basis. [18].

The second type of nanotubes may experience another mechanism of growth

According to the nucleation theory, growth species with higher probability will condense at places with a higher number of neighbour particles such as defects, steps, edges.

For an atomically flat 2D growth surface without defects and steps, higher binding energies at the edges will enable selective condensation of growth species at the edges. For $\mathrm{ZnO}$, it is well known that the growth rate along the c-axis is relatively faster; thus, if the decreased growth temperature is low enough to suppress migration along the 2D surface of the c-plane but high enough to sustain the growth along the $\mathrm{c}$ axis, the condensation and growth will be limited at the edges of the c-plane of $\mathrm{ZnO}$ that causes the formation of nanotubes on the nanorod base.

The dominating growing mechanism depends on $\mathrm{Zn}$-terminated or O-terminated plane completes $\{002\}$ plane at the end of the first stage of growth before lowering the temperature.

Experimentally found duration of growth stages provides optimal dimensions and etching intensity of the obtained nanostructures, when nanotubes are sufficiently etched, but are not fully destroyed [13].

\subsection{Analysis of Morphology and Structural Properties}

Morphological and structural composition of the obtained sample was determined using the scanning electron microscope TESCAN-VEGA LMU II.

For structural and phase composition determination, XRD spectra were ob-

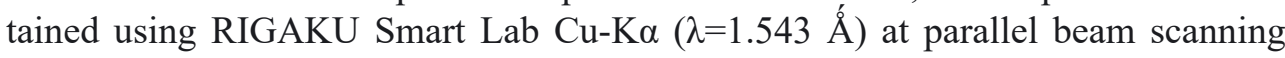
geometry and additional $\mathrm{Ge}(220) \times 2$ bounce monochromator.

\subsection{Analysis of Lead Ion Adsorption Process}

Optical measurements were carried out by Shimatzu spectrophotometer.

With the aim to analyse adsorption processes of $\mathrm{Pb}^{2+}$ ions using $\mathrm{ZnO}$ nanotubes as a sorbent, lead nitrate aqueous solution of different concentrations $(30 \mathrm{mM} / 1$ $300 \mathrm{mM} / \mathrm{l}$ ) was obtained (see reaction 5).

$$
\mathrm{Pb}\left(\mathrm{NO}_{3}\right)_{2} \leftrightarrow \mathrm{Pb}^{2+}+2 \mathrm{NO}_{3}^{-}
$$

Glass plates covered with nanotubes were placed into cuvette containing zinc nitrate aqueous solution and transmittance spectrum measurements for each concentration were carried out. 
For comparison purposes, the same procedure was carried out for nanorodcovered plates obtained at $0.1 \mathrm{M}$ equimolar $\mathrm{Zn}\left(\mathrm{NO}_{3}\right)_{2}$ and HMTA solution at $90{ }^{\circ} \mathrm{C}$ for $3 h$.

Chemical composition of adsorbed layer was determined by INCA EDS, but for phase composition determination XRD spectra were taken.

Deposition mechanism was explained as precipitation due to covalent bond formation between $\mathrm{Pb}$ (II) ions and $\mathrm{ZnO}$ surface (A bond). Donor-acceptor or coordination bond is also possible between surface of $\mathrm{ZnO}$ and $\mathrm{Pb}$ (II) (B bond) (Fig. 2 e) [4].

As shown in [2], the adsorption process depends on $\mathrm{pH}$ of solution. When $\mathrm{pH}>$ $\mathrm{pH}_{\mathrm{pzc}}$, where $\mathrm{pH}_{\mathrm{pzc}}$ is $\mathrm{pH}$ level at a zero charge point, chelate complexes between $\mathrm{ZnO}$ nanoparticles and $\mathrm{Pb}$ ions form. At a low $\mathrm{pH}$ level, chelate sites occupy $\mathrm{H}^{+}$making them neutral. This adsorption mechanism is preferential, but also a small amount of $\mathrm{Pb}$ (II) can be adsorbed at $\mathrm{pH}<\mathrm{pHpzc}$ during the ion exchange mechanism. It means that $\mathrm{Pb}^{2+}$ has greater affinity to $\mathrm{ZnO}$ compared with $\mathrm{H}^{+}$so that $\mathrm{H}^{+}$can be exchanged by metal ion during ion exchange. Ion exchange process occurs more slowly than surface complexation (formation of chelate complexes) during presence of organic molecular impurities on surface of $\mathrm{ZnO}$ nanostructures, which causes steric factor during the metal ion adsorption process.

\section{RESULTS AND DISCUSSION}

SEM images and XRD spectra of the obtained $\mathrm{ZnO}$ nanotubes samples are shown in Fig. 1.
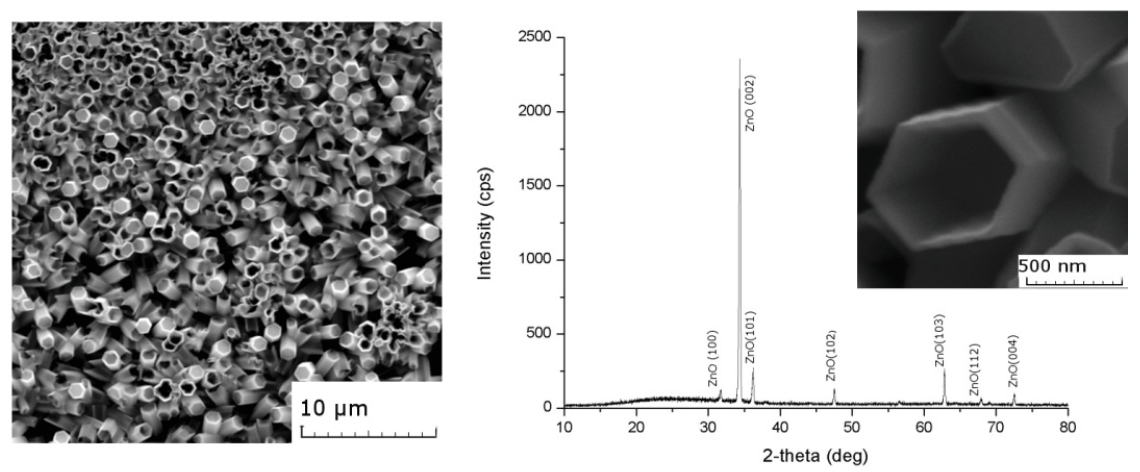

Fig. 1. SEM image of the prepared $\mathrm{ZnO}$ nanotubes and XRD pattern of the obtained nanostructures. Inset displays high-resolution SEM image of single nanotube with wall thickness of about $50 \mathrm{~nm}$.

The array of obtained nanotubes is well aligned with the preferred orientation along vertical direction as evidenced by higher peak intensity compared to another that corresponds to $\{002\}$ plane. Low intensity of amorphous background indicates that samples are highly crystallized and the analysis of the obtained peak shows no mismatching in the presence of $\mathrm{ZnO}$ crystalline phase.

For $\mathrm{Pb}^{2+}$ ion adsorption process analysis, samples were cut into narrow strips and placed to the Petri dish containing $300 \mathrm{mM} / 1-30 \mathrm{mM} / 1 \mathrm{~Pb}\left(\mathrm{NO}_{3}\right)_{2}$ aqueous solution under continuous stirring. 
SEM images display (Fig. 2) that by decreasing concentration of working solution the size of crystallites, which were formed due to the adsorption process, significantly increases. This is due to the fact that at high concentration of precursor growth particles with higher probability cooperate to create new seed grain instead of participating in the existing grain.

Chemical composition determined by EDS shows that deposition of lead ions occurs intensively, the sediment contains only $\mathrm{Zn}$ and $\mathrm{O}$ and XRD pattern of sample after adsorption procedure confirms (Fig. 3) that sediment consists of different kinds of lead oxides and monoclynic $\alpha$-modification of $\mathrm{Pb}_{2} \mathrm{O}_{3}$ and rhombic $\mathrm{Pb}_{3} \mathrm{O}_{2}\left(\mathrm{NO}_{3}\right)_{2}$ are the most widely represented ones. Corresponding to the shape of each crystal system, crystallites are observed from SEM images.

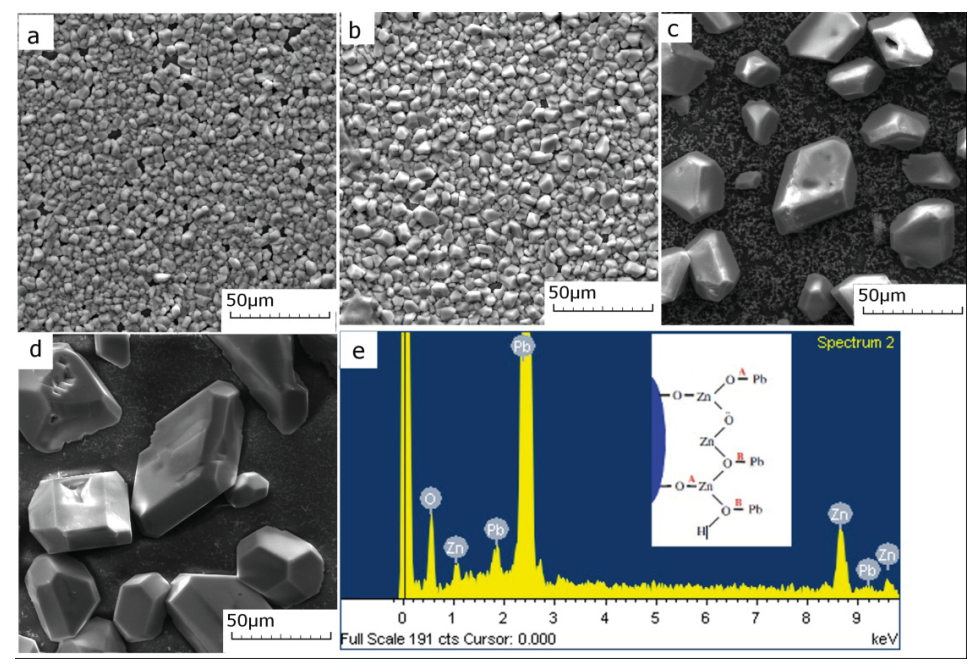

Fig. 2. SEM images of lead sediment on surface of $\mathrm{ZnO}$ nanotubes obtained at different concentrations of $\mathrm{Pb}\left(\mathrm{NO}_{3}\right)_{2}$ aqueous solution (a) $300 \mathrm{mM} / 1$, (b) $150 \mathrm{mM} / 1$, (c) $75 \mathrm{mM} / 1$,(d) $30 \mathrm{mM} / 1$, (e) EDS spectra of the obtained sample and schematic description of lead ion adsorption mechanism.

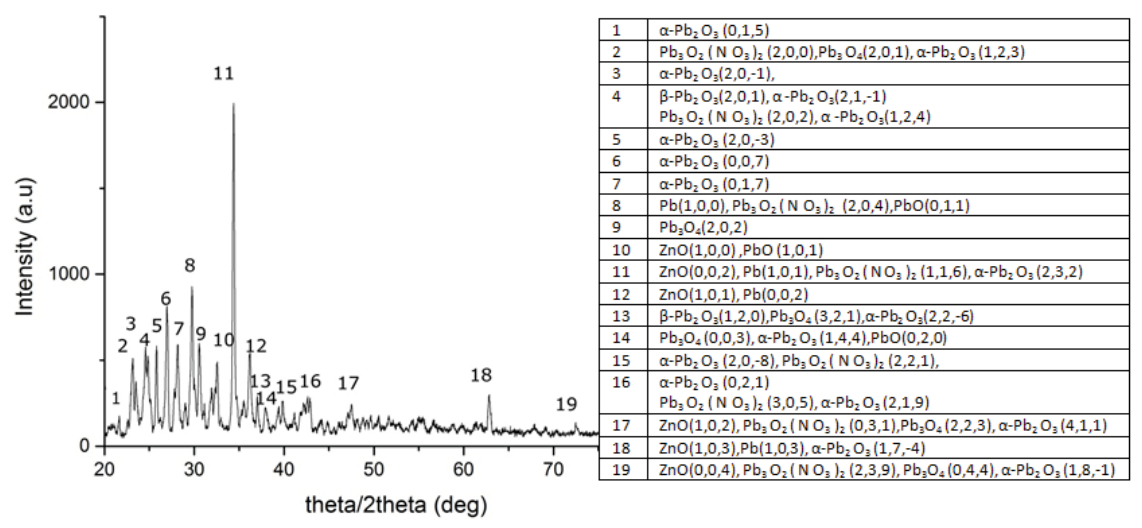

Fig. 3. XRD pattern of $\mathrm{ZnO}$ sample after lead ion adsorption.

Capacity of static adsorption was determined by equation (1).

$$
q_{e}=\frac{\left(C_{0}-C_{e}\right) V}{m},
$$


where $\mathrm{q}_{\mathrm{e}}$ is the amount of adsorbed $\mathrm{Pb}$ (II) $\left(\mathrm{mg} \mathrm{g}^{-1}\right), C_{0}$ and $C_{e}$ are the initial and equilibrium concentration of $\mathrm{Pb}(\mathrm{II})$ ions in solution $\left(\mathrm{mg} \mathrm{L}^{-1}\right)$, respectively, $V$ is volume of solution (L) and $m$ is sorbent mass $(\mathrm{g})$.

Calculations show that static adsorption capacity of $\mathrm{ZnO}$ nanotubes and nanorods obtained under the same conditions is $611 \mathrm{mg} / \mathrm{g}$ and $256 \mathrm{mg} / \mathrm{g}$, respectively. Measurements were taken at room temperature using $300 \mathrm{mM} / 1$ solution and immersing for $5 \mathrm{~min}$.

The obtained values mean that $\mathrm{ZnO}$ nanotubes in comparison with nanorods show better sorption properties per mass unit of sorbent for $\mathrm{Pb}^{2+}$ ion due to a larger effective surface and they are higher than that of $\mathrm{ZnO}$ nanorods and hollow microspheres as indicated in [2], [4], [10].

Optical transmittance spectra were taken with the aim to obtain the additional information about lead adsorption process on surface of $\mathrm{ZnO}$ nanotubes.

For this purpose, $\mathrm{ZnO}$ nanotube-coated glass plates were placed into a cuvette containing distilled water and the obtained spectra were accepted as a reference. Then water was replaced with $300 \mathrm{mM} / 1-30 \mathrm{mM} / 1 \mathrm{~Pb}\left(\mathrm{NO}_{3}\right)_{2}$ aqueous solution and spectra were carried out repeatedly, with different time delay of 0-30 min, in order to track lead sedimentation process in time and find out differences.

As shown in Fig. 4, during the reference experiment only one absorption edge at $380 \mathrm{~nm}$ corresponding to pure $\mathrm{ZnO}$ was observed.

When water was replaced with different concentrations of lead nitrate solution, distinct differences were observed for each concentration: $\mathrm{ZnO}$ corresponding adsorption edge was shifted to a shorter wavelength area that indicated structural changes in $\mathrm{ZnO}$ due to precipitation of lead oxide and, apart from the main absorption edge corresponding to $\mathrm{ZnO}$, the second absorption edge appeared and its value at $350 \mathrm{~nm}$ corresponded to the value specified for lead oxide by [19].

According to time differences of the obtained spectra, the adsorption process occurred rapidly: strong differences in shape of transmittance spectra were observed only for "as immersed" sample compared to the reference sample when the second absorption edge appeared immediately after immersion and the shape of spectra was constant during the entire experiment: by increasing time delay between two measurements only a change in intensity was observed, and there was no shape change. Differences in the intensity of spectra increased along with a decrease in lead nitrate concentration: at maximal $10 \%$ concentration spectra almost had no changes in time and after $30 \mathrm{~min}$ immersion had a slight difference in intensity compared to spectra of "as immersed" sample.

It should be noted that at higher concentration, changes in the transmittance value compared to the reference measurement with distilled water were observed immediately without time delay when lead nitrate solution was poured ("as immersed" samples), but in case of less concentration such as $2.5 \%$ and $1 \%$ an increase in transmittance was not observed during "as immersed" measurement (spectra were practically the same to the reference with the only difference being the second adsorption edge) and appeared only after 15-30min of time delay.

By comparing transmittance spectra of $\mathrm{ZnO}$ nanotubes and nanorods (Fig. 5), it can be concluded that nanorods have a time lag according to the adsorption 
process: after changing distilled water to lead nitrate solution no changes in intensity and no second adsorption edge corresponding to lead oxide are observed at first (Fig. 5a) and they appear only in 20-30 min, despite the fact that for tubes obtained under the same condition the second adsorption edge appears immediately (Fig. 5b).
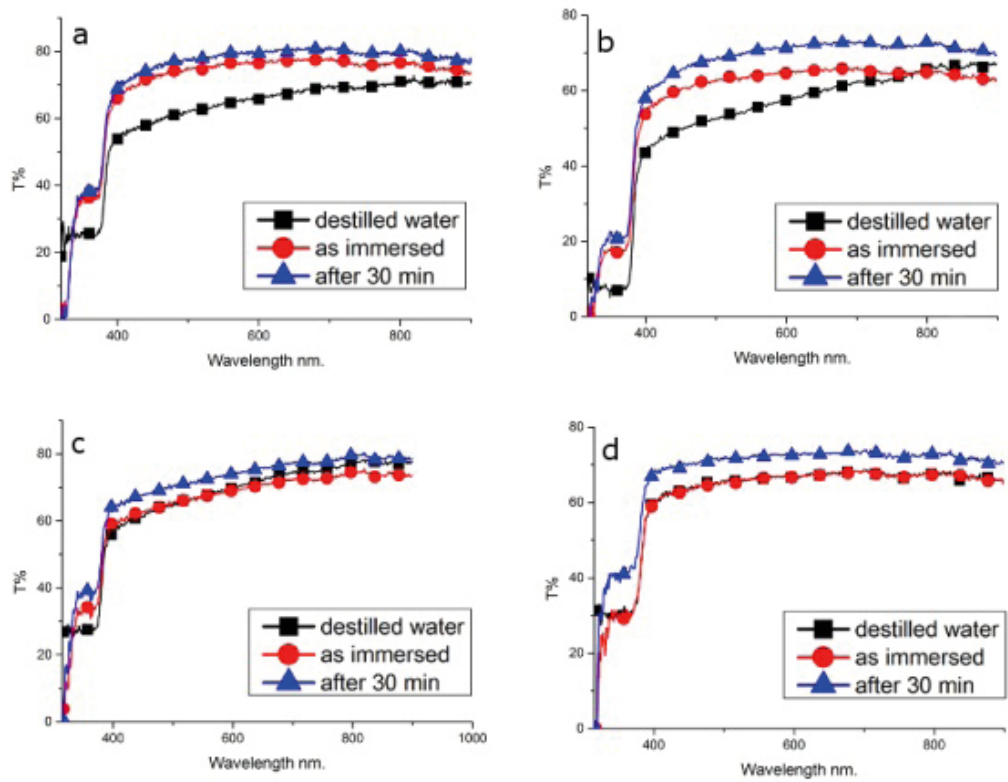

Fig. 4. Transmittance spectra of $\mathrm{ZnO}$ nanotubes immersed in various concentrations of $\mathrm{Pb}\left(\mathrm{NO}_{3}\right)_{2}$ aqueous solution. a) $10 \%$, b) $5 \%$, c) $2.5 \%$, d) $1 \%$.
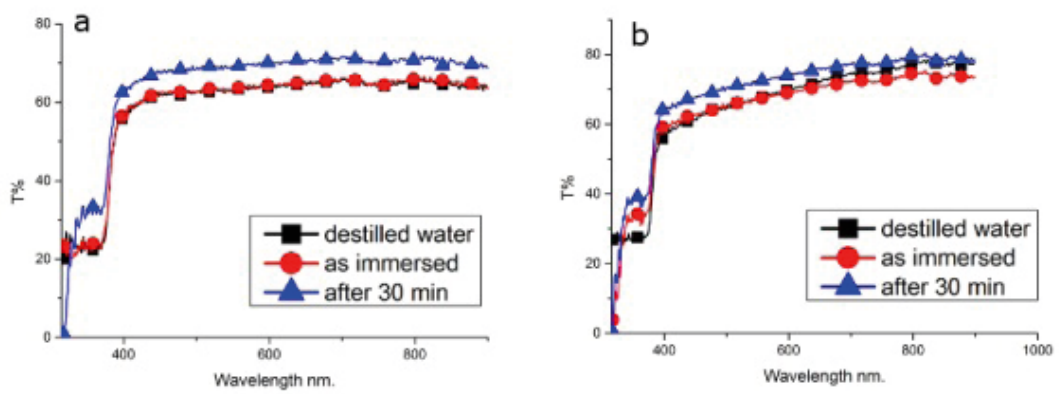

Fig. 5. Comparison of transmittance spectra of $\mathrm{ZnO}$ nanorods and nanotubes. Measurements were carried out using $2.5 \% \mathrm{~Pb}\left(\mathrm{NO}_{3}\right)_{2}$ aqueous solution. a) $\mathrm{ZnO}$ nanorods, b) $\mathrm{ZnO}$ nanotubes.

\section{CONCLUSIONS}

In the present research, well-aligned $\mathrm{ZnO}$ nanotube arrays have been obtained using a hydrothermal growth method, and then they have been used as a sorbent to evaluate efficiency of sedimentation process of lead ions on $\mathrm{ZnO}$ surface with the aim to apply $\mathrm{ZnO}$ nanostructures as a sorbent for water purification from lead contaminants.

It has been determined that lead precipitates to $\mathrm{ZnO}$ as a blend of different kinds of lead oxides $\left(\mathrm{PbO}, \mathrm{Pb}_{2} \mathrm{O}_{3}, \mathrm{~Pb}_{3} \mathrm{O}_{4}\right)$ and pure lead $(\mathrm{Pb})$. 
The experiment has shown that $\mathrm{ZnO}$ nanotube array demonstrates an approximately twofold higher value of static adsorption capacity $(>600 \mathrm{mg} / \mathrm{g})$ than that of $\mathrm{ZnO}$ nanorods grown under the same conditions.

Optical measurements have shown that $\mathrm{ZnO}$ nanotubes have higher responsiveness and sensibility to changes in the concentration of lead nitrate solution.

Detection of lead ions in aqueous solution can be carried out through the analysis of change in the shape of transmittance spectra: due to sedimentation process, the second absorption edge appears and $\mathrm{ZnO}$ adsorption edge shifts to a short wave region.

\section{REFERENCES}

1. Amin, M.T., Alazba, A.A., \& Manzoor, U. (2014). A review of removal of pollutants from water/wastewater using different types of nanomaterials, Adv. Mater.Sci. Eng., 1-24.DOI: http://dx.doi.org/10.1155/2014/825910.

2. Singh, S., Barick, K.C., \& Bahadur, D. (2013). Functional oxide nanomaterials and nanocomposites for the removal of heavy metals and dyes. Nanomater. Nanotechnol, 3(20). DOI 10.5772/57237.

3. Rahman, M.M., Bahadar, K., Hadi, S., \& Marwani, M. (2014). Low dimensional Ni$\mathrm{ZnO}$ nanoparticles as marker of toxic lead ions for environmental remediation, J.Ind. Eng. Chem. 20(3), 1071-1078. DOI: 10.1016/j.jiec.2013.06.044.

4. Zolfaghari, G., Esmaili-Sari, A., Anbia, M., Younesi, H., Ghasemian, M.B. (2013). A zinc oxide-coated nanoporous carbon adsorbent for lead removal from water: optimization, equilibrium modeling, and kinetics studies. Int. J. Environ. Sci. Technol., 10, 325-340. DOI: 10.1007/s13762-012-0135-6.

5. Srivastava, S., \& Srivastav, Y. (2013). Removal of arsenic from waste water by using ZnO nano-materials. J.Mater. Sci.Eng. B, 3(8), 483-492.

6. Khan, S.B., Rahman, M.M., Marwani, H.M., Asiri A.M., \& Alamry, K.A. (2013). An assessment of zinc oxide nanosheets as a selective adsorbent for cadmium. Nanosc. Res. Lett. 8, 377. DOI: 10.1186/1556-276X-8-377.

7. Rahman, M.M., Khan, S.B. Asiri, A.M., Marwani, H.M., \& Qusti, A.H. (2013). Selective detection of toxic $\mathrm{Pb}$ (II) ions based on wet-chemically prepared nanosheets integrated CuO-ZnO nanocomposites, Comp. B, 54, 215-223. DOI:http://dx.doi.org/10.1016/j. compositesb.2013.05.018.

8. Kannadasan, N., Shanmugam, N., Sathishkumar, K., Cholan, S., Ponnguzhali, R., \& Viruthagiri, G. (2015).Optical behavior and sensor activity of $\mathrm{Pb}$ ions incorporated $\mathrm{ZnO}$ nanocrystals. Spectrochim. Acta A: Molecul. Biomolecul. Spectrosc. 143, 179-186. DOI: http://dx.doi.org/10.1016/j.saa.2015.01.113.

9. Erdem, M., Ucar, S. Karagöz, S., \& Tay, T. (2013). Removal of Lead (II) Ions from Aqueous Solutions onto Activated Carbon Derived from Waste Biomass. Sci.World. J., 7. DOI: http://dx.doi.org/10.1155/2013/146092.

10. Xianbiao, W., Weiping, C., Shengwen, L., Guozhong, W., Zhikun, W., \& Huijun Z. (2013). ZnO hollow microspheres with exposed porous nanosheets surface: Structurally enhanced adsorption towards heavy metal ions. Colloids and Surfaces A: Physicochem. Eng. Aspects, 422, 199-205. DOI:http://dx.doi.org/10.1016/j.colsurfa.2013.01.031.

11. Wang, X., Guo, Y., Yang, L., Han, M., \& Zhao, J. (2012). Nanomaterials as sorbents to remove heavy metal ions in wastewater treatment. J. Environ. Anal. Toxicol. 2(7), 154. DOI:10.4172/2161-0525.1000154. 
12. Yeong, H.K., Dandu, K.V.R., and Jae, S.Y. (2013). Electrochemical synthesis of ZnO branched submicrorods on carbon fibers and their feasibility for environmental applications. Nanoscale Research Letters, 8, 262.

13. Krasovska, M., Gerbreders, V., Paskevics, V. Ogurcovs, A., \& Mihailova, I. (2015). Obtaining a well- aligned $\mathrm{ZnO}$ nanotube array using the hydrothermal growth method. Latvian J. Phys.Techn.Sci. 5(52), 28-40. DOI: 10.1515/lpts-2015-0026.

14. Chae, K., Zhang, Q., Kim, J.S, Jeong, Y., \& Cao, G. (2010). Low-temperature solution growth of $\mathrm{ZnO}$ nanotube arrays. Beilstein J.Nanotechnol, 1, 128-134. DOI:10.3762/ bjnano.1.15.

15. Roza, L., Rahman, M.Y.A., Umar, A.A., \& Salleh, M.M. (2015). Direct growth of oriented $\mathrm{ZnO}$ nanotubes by self-selective etching at lower temperature for photo-electrochemical (PEC) solar cell application. J. All.Comp., 618, 153-158. DOI:10.1016/j.jallcom.2014.08.113.

16. Song, Y., Xi, J., Xu S., Yang, R., Gao, Z., Hu, C., \& Wang, Z. (2009). Growth of ZnO nanotube arrays and nanotube based piezoelectricnanogenerators. J. Mater. Chem., 19(48), 9260-9264. DOI: 10.1039/B917525C.

17. Hongqiang, W., Guanghai, L., Lichao, J., Guozhong, W., \& Chunjuan, T. (2008). Controllable preferential-etching synthesis and photocatalytic activity of porous $\mathrm{ZnO}$ nanotubes. J. Phys. Chem. C, 112(31), 11738-11743. DOI: 10.1021/jp803059k.

18. Yap, Y.K. (2009). Growth mechanisms of vertically-aligned carbon, boron nitride, and zinc oxide nanotubes. AIP Conf. Proc. 1150, 126. DOI: 10.1063/1.3192226.

19. Alfind, A., Frit, P., Deepalakshmi, K., Prithivikumaran, N., \& Jeyakumaran, N. (2014). The effect of annealing time on lead oxide thin films coated on indium tin oxide substrate. Int. J. ChemTech Res., 6(13), 5347-5352.

\title{
SVINA JONU ADSORBCIJAS PROCESU ANALĪZE UZ LABI SAKĀRTOTU ZnO NANOCAURUL̨U VIRSMAS
}

\author{
M. Krasovska, V. Gerbreders, E. Tamanis, S.Gerbreders, A.Bulanovs
}

$$
\text { Kopsavilkums }
$$

Darba procesā izmantojot hidrotermālo metodi tika iegūtas labi sakārtotas $\mathrm{ZnO}$ nanostieṇu un nanocauruḷu kopas.

Tika izpētītas doto paraugu sorbcijas īpašības attiecībā uz svina jonu nogulsnēšanos no svina nitrātu saturoša ūdens šķīduma ar mērķi noteikt abu veidu efektivitāti izmantošanā kā sorbentu ūdens attīrīšanai no svinu saturošiem piemaisījumiem.

Ir konstatēts, ka ZnO virsma piesaista svina jonus dažādu oksīdu maisījuma veidā $\left(\mathrm{PbO}, \mathrm{Pb}_{2} \mathrm{O}_{3}, \mathrm{~Pb}_{3} \mathrm{O}_{4}\right)$ un arī kā tīru metālu $(\mathrm{Pb})$.

Eksperiments pierāda, ka nanocaurulēm piemīt ievērojami lielāka statiskās absorbcijas kapacitātes vērtība, nekā nanostieņiem $(\approx 600 \mathrm{mg} / \mathrm{g})$ un $(\approx 256 \mathrm{mg} / \mathrm{g})$ atbilstoši. Svina jonu eksistenci var konstatēt arī spektroskopiski, analizējot ZnO nanostruktūru caurlaidības spektra izmaiņas: nogulsnēšanās procesā parādās otrā absorbcijas mala, kā arī primārā ZnO atbilstoša absorbcijas mala tiek nobīdīta īsviḷ,nu apgabalā.

10.11.2016. 